\title{
Öğretmen Mesleki Motivasyonu Ölçeği Geçerlik ve Güvenirlik Çalışması: Çevrimiçi ve Kâğıt Kalem Uygulamalarının Karşılaştırılması *
}

\author{
Esra KARABAĞ KÖSE ${ }^{1}$ Erdem KARATAŞ ${ }^{2}$ Mehmet KÜÇÜKÇENE ${ }^{3}$ Ali TAŞ ${ }^{4}$
}

- Geliş Tarihi: 23.03.2020 • Kabul Tarihi: 08.08.2020 • Yayın Tarihi: 19.10.2020

\section{$\ddot{\mathbf{O} z}$}

$\mathrm{Bu}$ çalışmada, öğretmenlerin mesleki motivasyon düzeylerinin belirlenmesine yardım edecek geçerli ve güvenilir bir ölçme aracı geliştirmek amaçlanmıştır. Araştırmaya toplam 1054 ilkokul, ortaokul ve lise öğretmeni katılmıştır. Uygulamanın son aşamasında doğrulayıcı faktör analizi verileri çevrimiçi uygulama ile toplanmıştır. Araştırma bulguları, Öğretmen Mesleki Motivasyonu Ölçeği'nin okul içi faktörler, okul dışı faktörler, mesleki gelişim ve saygınlık ve fiziki imkânlar olmak üzere dört alt boyuttan oluştuğunu göstermektedir. Doğrulayıcı faktör analizi sonuçları, ölçeğin dört faktörlü yapısının kabul edilebilir uyum gösterdiğini ortaya koymaktadır. Kâğıt kalem testi uygulamasının ortaya koyduğu faktör yapısı çevrimiçi uygulama ile de doğrulanmıştır. Ölçeğin alt boyutlarına ilişkin iç güvenirlik katsayıları, hem kâğıt kalem uygulaması için hem de çevrimiçi uygulama için kabul edilebilir sınırların üzerindedir. Araştırma sonucunda, ölçeğin kâğıt kalem ve çevrimiçi formlarının okullarda öğretmen motivasyonunu değerlendirmek üzere kullanılabilecek geçerli ve güvenilir bir ölçme aracı olduğuna ilişkin güçlü kanıtlara ulaşılmıştır.

Anahtar sözcükler: öğretmen motivasyonu, ölçek geliştirme, çevrimiçi uygulama, kâğıt kalem uygulamas1

\section{Atıf:}

Karabağ Köse, E., Karataş, E., Küçükçene, M. ve Taş, A. (2021). Öğretmen mesleki motivasyonu ölçeği geçerlik ve güvenirlik çalışması: çevrimiçi ve kâğıt kalem uygulamalarının karşılaştırılması. Pamukkale Üniversitesi Eğitim Fakültesi Dergisi, 51, 479498.doi:10.9779.pauefd.707619

\footnotetext{
* Bu çalışma 1-4 Kasım 2018 tarihinde 9. Uluslararası Eğitim Yönetimi Forumu EYFOR-9'da sözlü bildiri olarak sunulmuş olup, Kırıkkale Üniversitesi Bilimsel Araştırma Projeleri Koordinasyon Birimi tarafından, 2017/054 numaralı proje kapsamında desteklenmiş, 12.08.2019 tarihinde tamamlanmıştır.

1 Doç. Dr., Kırıkkale Üniversitesi, Eğitim Fakültesi Eğitim Bilimleri Bölümü, esrakarabag@gmail.com, https://orcid.org/0000-0003-1367-7793

2 Arş. Gör., Kırıkkale Üniversitesi, Eğitim Fakültesi Eğitim Bilimleri Bölümü, erdemkaratas068@ gmail.com, https://orcid.org/0000-0002-7841-4815

3 Arş. Gör., Kırıkkale Üniversitesi, Eğitim Fakültesi Eğitim Bilimleri Bölümü, mehmetkcene@hotmail.com, https://orcid.org/0000-0001-6405-7995

4 Prof. Dr., Kırıkkale Üniversitesi, Eğitim Fakültesi Eğitim Bilimleri Bölümü, atas865@gmail.com, https://orcid.org/0000$\underline{0002-3344-3911}$
} 


\section{Giriş}

Eğitim, psikoloji, sosyoloji ve yönetim gibi sosyal bilim alanlarında araştırmacıların ilgisini en fazla çeken kavramlardan birisi motivasyon kavramıdır. Motivasyon tanımları incelendiğinde ortak paydada; insanda davranışı ortaya çıkaran, yönlendiren ve bu davranışın gücünü ve sürekliliğini belirleyen iç ve diş unsurların ön plana çıktığı görülmektedir (Han ve Yin, 2016; Ryan ve Deci, 2000; Pinder, 2014; Sieberer-Nagler, 2016). Bu bağlamda, insanın beşeri faaliyetlerini ve bir amaca yönelik hareketlerini belirleyen unsurların bireylerin düşünce, umut, inanç; başka bir deyişle kişinin arzu, ihtiyaç ve korkularından ileri geldiği söylenebilir (Eren, 2004).

Motivasyonla ilgili kavramsal ve pratik çalışmalarda en yaygın yaklaşımlardan birisi içsel ve dışsal motivasyon ayrımıdır. İçsel motivasyon, bireyden kaynaklanan motivasyon unsurları ile karakterize edilir. İçsel olarak motive edilmiş davranışlar, kendi çıkarları için ve kendi performanslarından elde edilen memnuniyet ve tatmin ile ilgilidir (Deci ve Ryan, 1985). İçsel motivasyon, algılanan dış uyaran veya ödül olmadığında bile eylemlere ilham verir. İçsel olarak motive olduklarında, insanlar kendilerini ilgilendiren faaliyetlerde bulunurlar ve özgürce, tam bir irade duygusuyla ve maddi ödül ya da kısıtlama gerekliliği olmadan bu davranışları sergilerler (Deci ve Ryan, 1985; Stirling, 2014). Dışsal motivasyon ise doğası gereği tatmin edici veya ilgi çekici olmayan, ancak algılanan potansiyel sonuçlar açısından faydalar sağlayabilecek eylemleri teşvik eder (Stirling, 2014). Dışsal motivasyon, teşvik edici unsurlar ya da dış güçler ile ortaya çıkabilir. Bu tür bir motivasyon, ceza ve ödül gibi etkilerden oluşur (Mahaney ve Lederer, 2006).

Motivasyon alanyazını incelendiğinde, kapsam ve süreç kuramları olmak üzere iki temel yaklaşımın geliştiği görülmektedir (Ryan ve Deci, 2011). Kapsam kuramları, kişinin davranışlarını yönlendirmede etkili olan motivasyon unsurlarına, başka bir deyişle nelerin bireyler üzerinde motivasyon sağladığına odaklanırken; süreç kuramları insan davranışının nasıl yönlendirilebileceğini belirleyen sürecin kendisini ele almaktadır (Koçel, 2005). Motivasyona ilişkin başlıca kapsam (içerik) kuramları; Maslow'un İhtiyaçlar Hiyerarşisi, Alderfer'in ERG Kuramı, Herzberg'in Çift Faktör Kuramı ve Başarı-Güç Kuramı iken; başlıca süreç kuramları arasında Vroom'un Beklenti Kuramı, Lawler ve Porter'in Geliştirilmiş Beklenti Kuramı, Ödül Adaleti (Eşitlik) Kuramı bulunmaktadır (Küçüközkan, 2016). 
Maslow, İhtiyaçlar Hiyerarşisi Kuramı ile insan ihtiyaçlarını; fizyolojik, güvenlik, ait olma, saygı ve kendini gerçekleştirme ihtiyacı olmak üzere beş grupta tanımlamaktadır. İhtiyaçlar hiyerarşik olarak gerçekleştiğinden dolayı, çalışanların fizyolojik ihtiyaçları karşılanmadan onlara sosyal bir ortam oluşturmanın motive edici olmayacağı ileri sürülmektedir. Başka bir deyişle, motivasyon için ilk adım ekonomik unsurların sağlanması ve daha sonra diğer ihtiyaçlar için hareket edilmesi önem arz etmektedir (Ergeneli ve Eryiğit, 2001). Maslow’un kuramı ile benzerlik gösteren Alderfer'in kuramında ise var olma ihtiyacı, aitlik ihtiyacı ve gelişme ihtiyacı olmak üzere üç temel ihtiyaç bulunmaktadır. Varoluş ihtiyacı, yeme-içme, maaş, iyi donanımlı ortamlar gibi maddi unsurları; aitlik ihtiyacı, bireyin çevresindeki diğer kişilerle olan ilişkileri; gelişme ihtiyacı ise bireyin üretme, ortaya bir şeyler koyması durumunu kapsamaktadır (Oksay, 2005). İnsan davranışını süreç olarak ele alan kuramların başında ise Vroom'un Beklenti kuramı sayılabilir. Bu kurama göre, bir davranışın ortaya koyulmasındaki unsurları bireyin kişiliği ve çevresi ile ilgili koşullar etkilemekte ve belirlemektedir. Ayrıca, farklı ihtiyaç, istek ve hedefleri olan insanlar, kendilerini ödüllere ulaştıracak farklı davranış şekillerinden kendi algılarına göre seçim yapmaktadırlar (Eren, 2004).

Yönetim alanında çalışanların iş performansını artırmaya yönelik tartışılan motivasyon kavramı, eğitim alanında ise öğrencilerin ve öğretmenlerin akademik performansını ve çalışma isteğini artırma bağlamında ele alınmaktadır. Öğretmenin mesleki bağlılığının belirleyici unsurlardan birisi olarak kabul edilen öğretmen motivasyonu (De Jesus ve Lens, 2005) eğitim bilimlerinin çeşitli alt disiplinlerinde yoğun çalış1lan konulardan birisidir. $\mathrm{Bu}$ çerçevede öğretmen motivasyonu alanyazınında, söz konusu değişkenin iş doyumu (Davis ve Wilson, 2000), sosyal iletişim becerileri (Doğan ve Koçak, 2014), örgütsel faktörler ve liderlik (Thoonen, Sleegers, Oort, Peetsma ve Geijsel, 2011), pozitif psikoloji (Viseu, De Jesus, Rus ve Canavarro, 2016) gibi farklı değişkenlerle ilişkilerini ortaya koymayı amaçlayan çok sayıda çalışma yer almaktadır.

Öğretmenlik mesleği, psikolojik ve sosyolojik dinamikleri bakımından pek çok mesleğe göre önemli farklılıklar göstermektedir. Öğrenciler, meslektaşlar, aileler ve diğer eğitim paydaşları ile etkileşim, öğretmenlik mesleğinin temel yeterlilik alanlarından birisini oluşturmaktadır. Bu bakımdan, mesleğin icrasında duygusal süreçlerin etkisinin, mesleki motivasyon dinamiklerini diğer mesleklere göre farklılaştırdığı ileri sürülebilir. Öğretmenler mesleki süreçler açısından; genel toplumsal beklentiler, öğrenci ve veli beklentileri, eğitim politikalarına bağlı olarak üst yönetimin beklentileri gibi çok farklı dinamiklerin doğrudan 
veya dolaylı olarak etkisi altındadır. Ng ve Ng’ye (2015) göre bir öğretmenin motivasyonu, temel olarak öğretmenin kişisel ilgi ve öğretime olan bağlılığı ile ilgilidir ve öğrenciler, meslektaşlar ve yönetim kadrolarından oluşan çalışma ortamından etkilenir. Aileler, öğrenciler, okul yöneticileri ve diğer meslektaşlarla etkileşim, ulusal eğitim politikaları gibi temel motivasyon kaynaklarının (Börü, 2018; Karabağ-Köse, Taş, Küçükçene ve Karataş, 2018) öğretmen motivasyonunu farklılaştırması beklenmektedir. Ayrıca eğitim ve okul vizyonunun paylaşılması gibi unsurların öğretmen motivasyonunu farklılaştırdı̆̆ söylenebilir (Kurt, 2005). Dolayısıyla öğretmen motivasyonunun, genel motivasyon süreçlerinin ötesinde, mesleğin özgün dinamikleri göz önüne alınarak değerlendirilmesi önem taşımaktadır. Diğer taraftan öğretmen motivasyonunu incelemeye yönelik pek çok ampirik çalışmada öğretmen motivasyonunun değerlendirilmesinde genel iş motivasyonu ölçeklerinden yararlanıldığı görülmektedir (Akman, 2018; Aksel ve Elma, 2018; Can, 2015; Güçlü, Recepoğlu ve Kılınç, 2014). Benzer bir eğilim farklı ülkelerde yürütülen öğretmen motivasyonu araştırmalarında da (Lind, 2017; Nie, Chua, Yeung, Ryan ve Chan, 2014) olmakla birlikte, uluslararası literatürde öğretmenin işle ilgili görevlerine yönelik geliştirilmiş ölçekler sınırlı da olsa yer almaktadır (Fernet, Senécal, Guay, Marsh ve Dowson, 2008; Roth, Assor, Kanat-Maymon ve Kaplan, 2007). Fernet ve arkadaşları (2008) mesleki görevlere ilişkin hazırladıkları ölçek geliştirme çalışmasında, sınıf yönetimi, öğretim, öğrencileri değerlendirme gibi mesleki görevlere yönelik öğretmen motivasyonunu ölçmeyi amaçlamışlardır. Roth ve arkadaşları (2007) ise öğretmenlerin özerk motivasyon deneyimlerine odaklandıkları çalışmalarında öğretim motivasyonunu ölçmeye odaklanmışlardır. Dolayısıyla sınırlı mesleki görevlerin ötesinde, öğretmen motivasyonunu daha genel bağlamda ele alan bir mesleki motivasyon ölçeğinin ilgili alanyazına katk1 sağlayacağı söylenebilir. Ayrıca böyle bir ölçek çalışmasının kültürel bağlama duyarlı olarak geliştirilmesi de önem taşımaktadır.

Dünyada yoğun tartışılan kavramlardan birisi olan motivasyon kavramı, kültürel ve toplumsal bağlamla yakın ilgisi olan bir olgudur. Neyin değerli olduğuna ilişkin duygusal kodların edinildiği toplumsal yapının kültürel özellikleri, bireyleri motive edecek unsurları da biçimlendirmektedir. Bir toplumda insanları harekete geçirebilecek bazı durumlar, başka bir toplumun bireyleri için aynı etkiyi göstermeyebilir. Buna göre motivasyon kavramının kültürel, toplumsal, kurumsal vb. özellikler temele alınarak değerlendirilmesi önemlidir (Demir ve Okan, 2009; Hofstede, 2001). Çalışmanın bu bağlamda, öğretmenlik mesleğinin psikolojik, toplumsal, kültürel ve kurumsal anlamda özgün dinamiklerini değerlendirmesi 

bakımından, Türk kültüründe öğretmen motivasyonu alanyazınına özgün bir katkı sağlayacağı düşünülmektedir. Alanyazında öğretmen motivasyonu ile ilgili yapılan çalışmaların pek çoğunda genel iş motivasyonu ölçeklerinin uyarlamalarının kullanılıyor olması (Akman, 2018; Çivilidağ ve Şekercioğlu, 2017; Dündar, Özutku ve Taşpınar, 2007; Emirbey, 2017; Güçlü ve diğerleri, 2014; Yılmaz, 2009), öğretmen motivasyonuna yönelik ölçek geliştirme çalışmalarında ise, genel olarak okul ve eğitim bağlamının tüm yönleri ile ele alınmaması ve/veya çalışmaların geçerlik ve güvenirlik kanıtlarının yeterli düzeyde sunulmaması (Akdemir ve Arslan, 2013; Bektaş, 2010; Polat, 2010) bu çalışmanın önemini artırmaktadır. Öğretmen motivasyonuna yönelik bazı ölçek geliştirme çalışmalarında ise (Akdemir ve Arslan, 2013; Ceviz, 2018; Öztürk ve Uzunkol, 2013) makro eğitim politikaları, veli ve öğrenci faktörleri gibi öğretmen motivasyonunu etkileyen faktörler kapsam dışı tutulmuştur. Öğretmenlerin motivasyon unsurlarını, okul içi ve okul dışı tüm yönleri ile değerlendirmeyi amaçlaması bakımından bu ölçek geliştirme çalışmasının ilgili alanyazına özgün bir katkı sağlaması beklenmektedir.

Öğretmen motivasyonunun değerlendirilmesi ile ilgili alanyazında dikkat çeken bir diğer husus ölçme araçlarının genellikle belirli alanlara (sınıf öğretmenliği, İngilizce öğretmenliği, fizik öğretmenliği vb.) özgü tasarlanmış olmasıdır (Carson ve Chase, 2009; Choi, 2014; Öztürk ve Uzunkol, 2013). Belirli alanlara odaklı bu ölçme araçlarının okuldaki tüm öğretmenlerin bir grup olarak değerlendirmeye alınmasını gerektiren nicel temelli ilişkisel araştırmalar için kullanışlı olmadığı düşünülmektedir. Bu bağlamda uluslararası alanyazında farklı kültürlerde geliştirilmiş genel anlamda öğretmen motivasyonu değerlendirmeye dönük ölçekler bulunmaktadır (Fernet ve diğerleri, 2008; Roth ve diğerleri, 2007). Türk kültüründe öğretmen motivasyonun incelenmesine yönelik araçların ise yukarıda söz edilen kapsam ve yapı geçerlikleri ile ilgili sınırlılıkları dolayısıyla bu çalışmanın alanyazında bir boşluğu doldurması beklenmektedir. Özellikle son yıllarda ampirik araştırmalarda çevrimiçi uygulamaların yaygınlaşması nedeniyle, ölçme araçlarının çevrimiçi ve klasik kağıt kalem uygulamalarının karşılaştırıldığı çalışmalara farklı alanlarda rastlanmaktadır (Ballester-Arnal, Castro-Calvo, Gil-Julia, Giménez-García ve Gil-Llario, 2019; Determann, Lambooij, Steyerberg, De Bekker-Grob ve De Wit, 2017). Mevcut çalışmada çevrimiçi ve kâğıt kalem uygulamalarına ilişkin geçerlik ve güvenirlik çalışmalarının karşılaştırmalı olarak yürütülmesi de çalışmanın öğretmen motivasyonu ile ilgili alanyazına özgün katkıları arasındadır. 
Bu bağlamda çalışmanın amacı, psikolojik, toplumsal, fiziksel, kültürel ve kurumsal özellikleri bakımından kendine özgü mesleklerden birisi olan öğretmenliği kendi özgün şartları içinde ele alan ve öğretmenlerin mesleki motivasyon düzeylerinin belirlenmesine yardım edecek geçerli ve güvenilir bir ölçme aracı geliştirmektir.

\section{Yöntem}

\section{Çalışma Grubu}

Araştırmanın çalışma evrenini ilkokul, ortaokul ve liselerde görev yapan öğretmenler oluşturmaktadır. Araştırma bir ölçek geliştirme çalışması olarak tasarlandığı için, her uygulamada, uygulanan madde sayısının en az 10 katı katılımcıya ulaşmak hedeflenmiştir (Tinsley ve Tinsley, 1987). Bu kapsamda; pilot uygulamada 286, kâğıt-kalem testiyle belirlenen geçerlik çalışmasında 345 ve çevrimiçi geçerlik çalışmasında 423 öğretmene ulaşılmıştır. Araştırmada toplam 1054 öğretmen araştırmaya dâhil olmuştur. Araştırmanın çalışma gruplarına ilişkin detaylar Tablo 1'de verilmiştir.

\section{Ölçme Aracının Geliştirilme Süreci}

Ölçme aracının geliştirilme sürecinde okul müdürleri ve öğretmenlerle görüşmeler yapılmış ve öğretmen motivasyonunu etkileyen faktörler farklı bakış açıları ile derinlemesine değerlendirilmiştir. Yapılan görüşmelere ve alanyazın incelemelerine dayalı olarak ölçek maddeleri hazırlanmıştır. Buna göre, mesleğe yönelik motivasyon unsurları operasyonel olarak tanımlanmış ve bu çerçevede öğretmenlerin mesleğe yönelik motivasyonunu etkileyen; veli, toplum, eğitim politika ve uygulamaları, öğrenci, öğretmen, yönetici vb. unsurlardan kaynaklanan faktörleri içeren 54 maddelik geniş kapsamlı bir madde havuzu oluşturulmuştur. Alan uzmanlarından alınan görüşler doğrultusunda maddelerin kapsam geçerliliği değerlendirilmiştir. Buna göre bazı maddeler ölçekten çıkartılmış, bazı maddeler birleştirilmiş ve pilot uygulama için 27 maddeden oluşan ilk form elde edilmiştir. Ölçme aracı için, 20 öğretmenin katılımı ile deneme uygulaması yapılmış ve ölçek maddelerinin açıklık ve anlaşılırlığı değerlendirilmiştir. 


\begin{tabular}{|c|c|c|c|c|c|c|}
\hline \multirow{4}{*}{$\begin{array}{l}\text { Demografik } \\
\text { Özellikler }\end{array}$} & \multicolumn{6}{|c|}{ Grup } \\
\hline & \multirow{2}{*}{\multicolumn{2}{|c|}{$\begin{array}{c}\text { Pilot } \\
\text { (Örneklem 1) }\end{array}$}} & \multirow{2}{*}{\multicolumn{2}{|c|}{$\begin{array}{l}\text { Kâğıt-Kalem } \\
\text { (Örneklem 2) }\end{array}$}} & \multirow{2}{*}{\multicolumn{2}{|c|}{$\begin{array}{c}\text { Çevrimiçi } \\
\text { (Örneklem 3) }\end{array}$}} \\
\hline & & & & & & \\
\hline & $\mathrm{n}$ & $\%$ & $\mathrm{n}$ & $\%$ & $\mathrm{n}$ & $\%$ \\
\hline \multicolumn{7}{|l|}{ Cinsiyet } \\
\hline Kadın & 154 & 53.85 & 191 & 55.36 & 224 & 52.96 \\
\hline Erkek & 132 & 46.15 & 154 & 44.64 & 199 & 47.04 \\
\hline \multicolumn{7}{|l|}{ Okul Türü } \\
\hline İlkokul & 104 & 36.36 & 137 & 39.71 & 118 & 27.90 \\
\hline Ortaokul & 95 & 33.22 & 114 & 33.04 & 142 & 33.57 \\
\hline Lise & 87 & 30.42 & 94 & 27.25 & 163 & 38.53 \\
\hline \multicolumn{7}{|l|}{ Branş } \\
\hline Sınıf Öğretmenliği & 87 & 30.42 & 104 & 30.14 & 97 & 22.93 \\
\hline Türkçe & 42 & 14.69 & 61 & 17.68 & 34 & 8.04 \\
\hline Sosyal Bilgiler & 26 & 9.09 & 24 & 6.96 & - & - \\
\hline Edebiyat & 16 & 5.59 & - & - & 16 & 3.78 \\
\hline Felsefe & - & - & 8 & 2.32 & - & 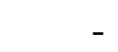 \\
\hline Yabancı Dil & 28 & 9.79 & - & - & 84 & 19.86 \\
\hline Matematik & 38 & 13.29 & 50 & 14.49 & 71 & 16.78 \\
\hline Özel Eğitim & - & - & 16 & 4.64 & - & - \\
\hline Din Kültürü & - & - & 43 & 12.46 & 79 & 18.68 \\
\hline $\begin{array}{l}\text { Bilişim } \\
\text { Teknolojileri }\end{array}$ & 15 & 5.24 & - & - & - & \\
\hline Diğger & 34 & 11.89 & 39 & 11.30 & 42 & 9.93 \\
\hline Toplam & 286 & 100.00 & 345 & 100.0 & 423 & 100.0 \\
\hline
\end{tabular}

Yapılan son düzenlemelerle nihai şekli verilen ölçme aracı için birinci aşama pilot uygulama kapsamında, 286 ilkokul, ortaokul ve lise öğretmeninin katılımıyla veri toplama çalışması yürütülmüştür. Birinci aşama uygulaması sonucunda ölçek maddelerinin madde toplam test korelasyonları değerlendirilmiş ve madde toplam korelasyonu .30'un altında kalan iki maddenin ölçekten çıkartılmasına karar verilmiştir. Elde edilen 25 maddelik 
E, Karabağ Köse, E, Karataş, M, Küçükçene ve A, Taş / Pamukkale Üniversitesi Eğitim Fakültesi Dergisi, 51, 479-498, 2021

ölçeğin geçerlik ve güvenirlik değerlendirmesini yapmak üzere 345 öğretmenin katılımı ile ikinci aşama olan kağıt-kalem uygulaması yapılmıştır. Son aşamada ise ölçeğin belirlenen faktör modelini doğrulamak üzere 423 öğretmenin katılımı ile çevrimiçi nihai uygulama gerçekleştirilmiştir.

\section{Verilerin Analizi}

Araştırmada kullanılan veri setlerinin normallik ve doğrusallık varsayımlarını karşılama durumları incelenmiştir. Maddeler bazında ve ölçek düzeyinde Mahalonobis uzaklıkları ile aykırı değer incelemeleri yapılmış, basıklık ve çarpıklık katsayıları değerlendirilmiştir ($2<\mathrm{z}<2 ; \mathrm{p}<.001)$. Veri dağılımlarının tekli ve çoklu normallik ile ilgili varsayımları karşıladığı görülmüştür. Ölçme aracının yapı geçerliğini değerlendirmek üzere, temel bileşenler analizi (TBA) ve doğrulayıcı faktör analizi (DFA) çalışmaları yapılmıştır. TBA için verinin faktör analizine ve faktör çıkarmaya uygunluğu KMO ve Bartlett testleri ile değerlendirilmiştir. KMO (.88) ve Bartlett testleri $\left(\mathrm{X}_{(345)}^{2}=3370.16 ; \mathrm{p}<.001\right)$ verinin uygun olduğunu göstermiştir. Ölçme aracının faktör yapısını değerlendirmek üzere yamaç grafikleri incelenmiş ve özdeğer 1 alınmıştır. Alt boyutların kuramsal olarak birbiri ile ilişkili olması nedeniyle eğik döndürme uygulaması tercih edilmiştir. Maddeler arası faktör yük değer farkları asgari .10 olarak alınmış, bir maddenin sahip olması gereken en düşük faktör yükü ise .32 kabul edilmiştir (Tabachnick ve Fidell, 2013). DFA için sık kullanılan uyum değerleri olan ki-kare uyum testi $(\chi 2)$, iyilik uyum indeksi (GFI), düzeltilmiş iyilik uyum indeksi (AGFI), yaklaşık hataların ortalama karekökü (RMSEA), karşılaştırmalı uyum indeksi (CFI), ve normlaştırılmış uyum indeksi (NFI) incelenmiştir (Gefen, Straub ve Boudreau, 2000; McDonald ve Ho, 2002). Güvenirlik için Cronbach Alpha iç tutarlılık katsayıları değerlendirilmiştir. Ölçeğin ayırt edicilik gücünü değerlendirmek üzere \%27’lik alt ve üst gruplar arasındaki farklılaşma MANOVA testi ile incelenmiştir.

\section{Bulgular}

İlk aşamada pilot uygulama için hazır hale getirilen 27 maddelik bir ölçme aracı, 286 öğretmenin (Örneklem 1) katılımıyla uygulanmıştır. Buna göre toplam madde korelasyonu .30'un altında kalan 17. maddenin (Telefon, BİMER vb. yollarla gelen şikâyetler motivasyonumu olumsuz etkiler.) ve 18. maddenin (Bu okulda ailelerin okula aşırı müdahil olması motivasyonumu olumsuz etkiler.) ölçekten çıkarılmasına karar verilmiştir. İlk aşama uygulama sonuçlarına göre ölçekte kalmasına karar verilen 25 maddenin madde toplam korelasyon değerleri .32 ile .62 arasında değişmektedir. 
İkinci aşamada 25 maddelik ölçme aracının yapısal özelliklerini değerlendirebilmek amacıyla farklı bir çalışma grubu verisi (Örneklem 2) üzerinde TBA yapılmıştır. TBA sonuçları Tablo 2'de yer almaktadır.

Tablo 2. Temel Bileşenler Analizi Sonuçları

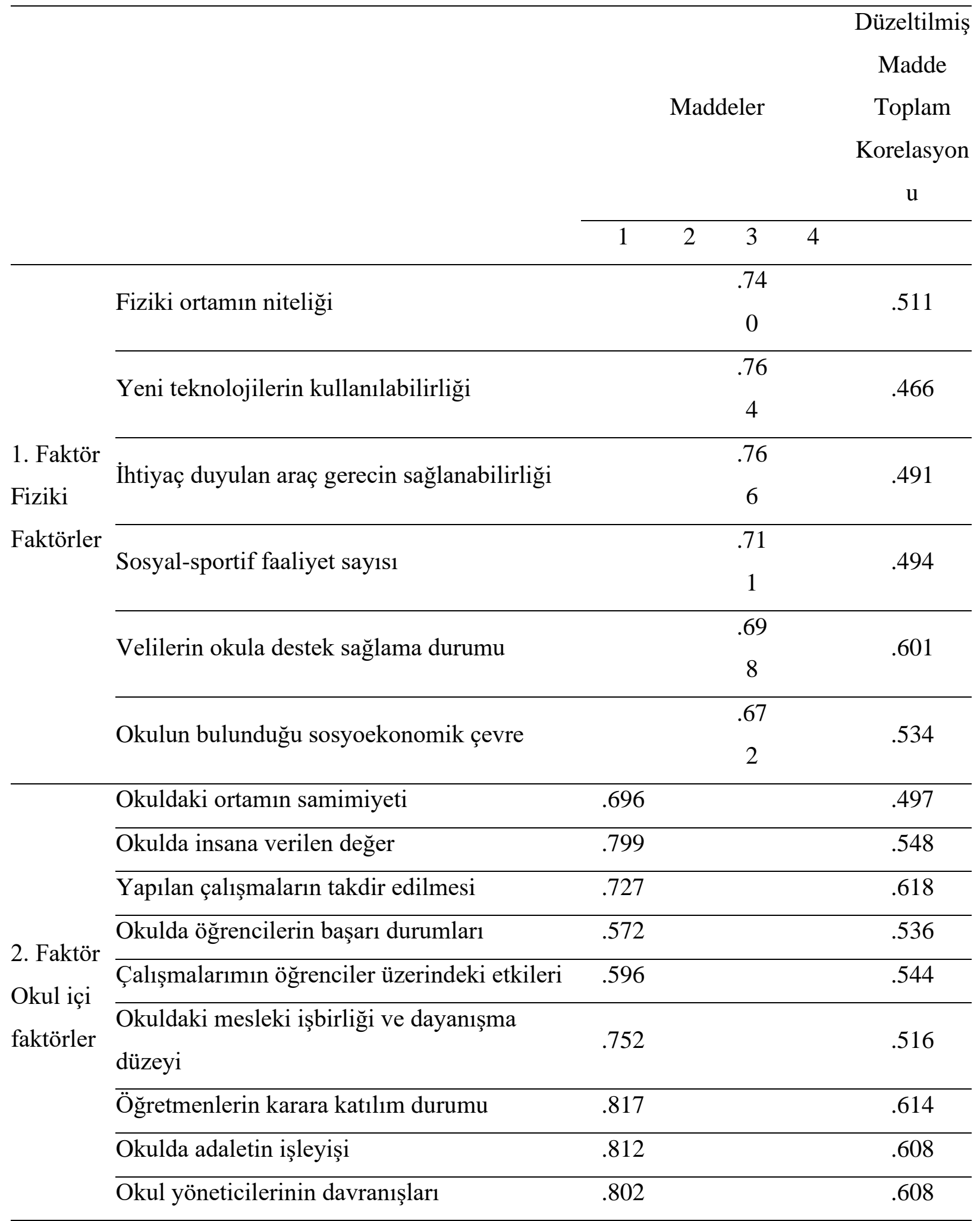


Ders saati, nöbet vb. taleplerin dikkate

alınmas1

Eğitim politika ve uygulamalarındaki değişimler

.644

.464

.824

3. Faktör

Okul Dışı

Bakanlıkça hazırlanan eğitim programları

Faktörler

Bakanlıkça hazırlanan ders kitapları

Mesleğin iş yükü

Aldığım ücret düzeyi

.618

442

Mesleğin saygınlığ1

.685

.484

4. Faktör

Mesleki Meslek sevgisi

.717

Gelişim

ve Kişisel ve mesleki gelişim imkânları

Saygınlık

.817

.543

Alanla ilgili yayınlara erişim (makale, dergi

vb.)

.470

.769

\begin{tabular}{lccccc}
\hline Özdeğer & 8.01 & 3.07 & 1.7 & 1.65 \\
& & & 8 & \\
\hline Açıklanan Varyans (\%) & 32.0 & 12.2 & 7.1 & \multirow{2}{*}{6.60} \\
& 3 & 8 & 2 & \\
\hline Açıklanan Toplam Varyans (\%) & \multicolumn{5}{c}{58.03} \\
\hline
\end{tabular}

Tablo 2 incelendiğinde 25 maddenin; fiziki imkânlar, okul içi faktörler, okul dış1 faktörler ve mesleki gelişim ve saygınlık olarak isimlendirilebilecek 4 ayrı faktöre ayrıldı̆̆ 1 görülmektedir. TBA sonucunda ölçekten çıkarılması gereken madde tespit edilmemiştir. Her bir faktörün açıklamış olduğu varyans \%6.6 ile \%32.03 arasında değişmektedir. Söz konusu faktörler toplam varyansın \%58.03'ünü açıklamaktadır. Maddelere ait düzeltilmiş madde toplam korelasyonları ile her bir faktörde yer alan maddelere ilişkin özdeğerler ve faktörlerin açıklamış olduğu toplam varyans Tablo 2'de ayrıntılı olarak sunulmaktadır.

TBA ile ortaya konulan faktör yapısının model uyumunu değerlendirmek amacıyla, hem 345 öğretmenden oluşan ikinci çalışma grubu (örneklem 2) verisi üzerinde, hem de 423 öğretmenden oluşan üçüncü çalışma grubu (örneklem 3) üzerinde DFA yapılmıştır. DFA sonuçları Şekil 1'de yer almaktadır. 

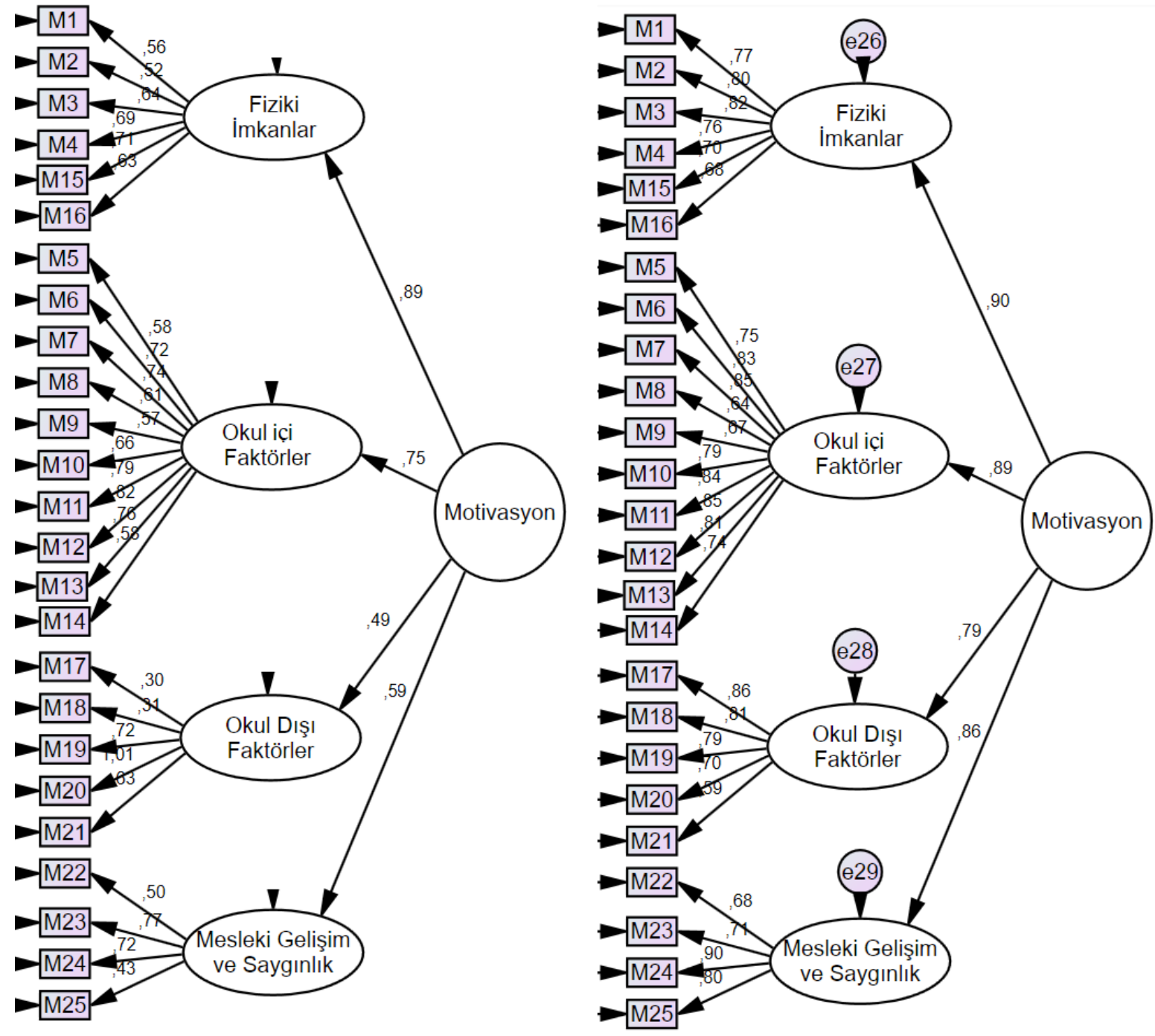

Şekil 1. Çevrimiçi (sol) ve kağıt-kalem (să̆) uygulamalarına ilişkin DFA sonuçları

Şekil 1'de görülen faktör yapısının ortaya koymuş olduğu uyum değerleri; kağıt kalem testi için $\left[\mathrm{X}^{2} / \mathrm{sd}=2.17\right.$; $\mathrm{RMSEA}=.06 ; \mathrm{GFI}=.86$; $\mathrm{AGFI}=.82 ; \mathrm{CFI}=.90$; ve $\left.\mathrm{NFI}=.83\right]$ ve çevrimiçi uygulama için $\left[\mathrm{X}^{2} / \mathrm{sd}=4.95 ; \mathrm{RMSEA}=.07\right.$; $\mathrm{GFI}=.88 ; \mathrm{AGFI}=.85 ; \mathrm{CFI}=.93$; ve NFI=.91] model uyumunun kabul edilebilir düzeyde olduğunu göstermektedir (Cole, 1987; Tabachnik ve Fidell, 2013). Maddelere ilişkin faktör yüklerini gösteren standartlaştırılmış regresyon ağırlıkları kağıt kalem uygulaması için .30 ile .82 arasında, çevrimiçi uygulama için ise .59 ile .90 arasında değişmektedir.

Ölçeğin güvenirlik özelliklerini değerlendirmek üzere iç tutarlılık katsayıları incelenmiştir. Ayrıca alt faktörler arası korelasyon değerleri incelenmiştir. Ölçek güvenirliğine ilişkin değerler Tablo 3 'te yer almaktadır. 
Tablo 3. Betimsel İstatistikler, Korelasyon ve İç Tutarlılık Katsayıları

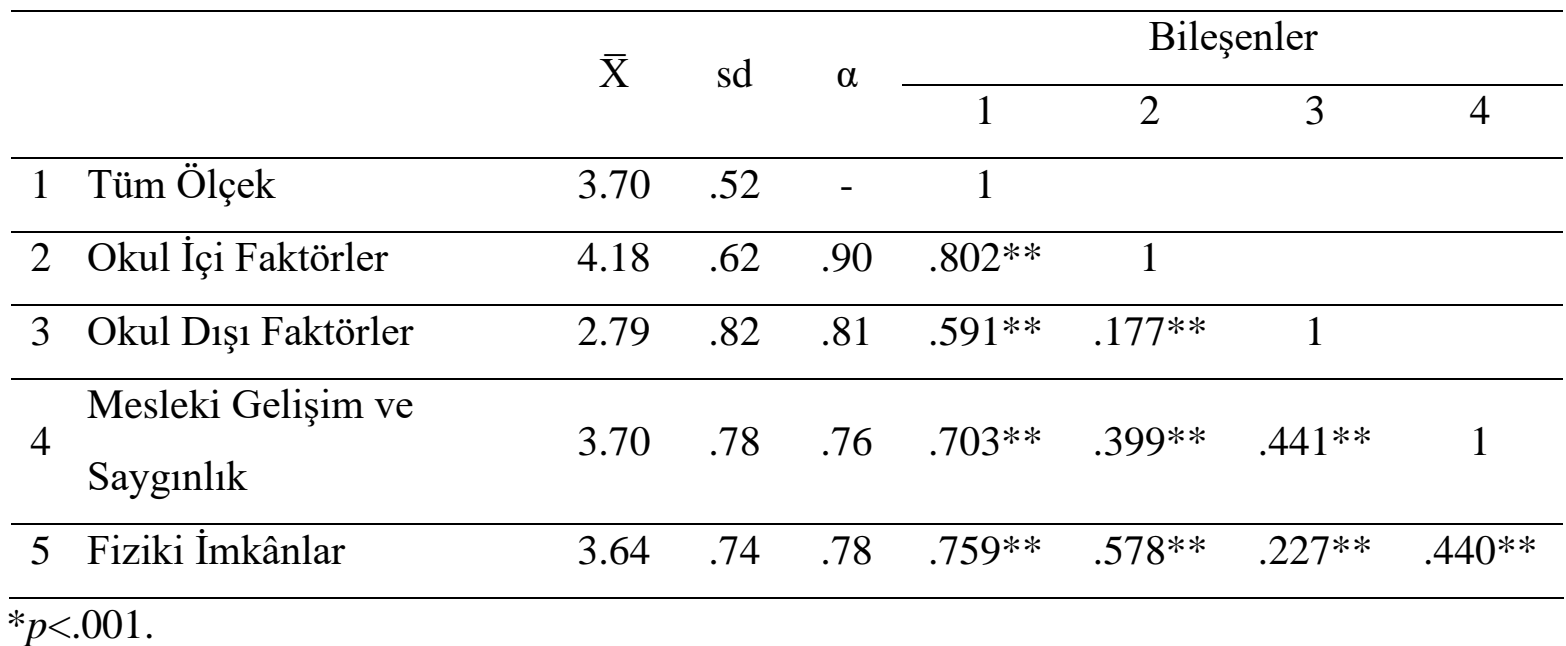

Tablo 3 incelendiğinde, nihai uygulama sonuçlarına göre ölçeğin güvenirlik değerlerinin her bir faktör için. 70 alt sınırının üzerinde olduğu görülmektedir. Ölçeğin alt faktörleri arasındaki korelasyon değerleri anlamlı ilişkiler ortaya koymakla birlikte, çoklu bağıntı açısından faktör birleştirmesini gerektirmemektedir $\left(\mathrm{r}_{(\max )}=.33\right)$. Diğer taraftan ölçek alt boyutlarının ölçeğin tümü ile korelasyonu yüksek bulunmuştur.

Ölçeğin ayırt edicilik gücünü değerlendirmek üzere \%27'lik alt ve üst gruplar arasındaki çoklu ortalama farklılıkları MANOVA testi ile değerlendirilmiştir. Buna göre çoklu varyans farklılıklarının anlamlı düzeyde olduğu görülmektedir $\left[\lambda=.15, F_{(5,123)}=136.49\right.$, $\mathrm{p}<.001]$. Ölçek ve alt ölçekler için alt ve üst gruplar arasındaki farklılaşma Tablo 4'te verilmiştir.

Tablo 4. Alt ve Üst Gruplar Arası Farklılaşma

\begin{tabular}{llllll}
\hline Faktörler & Gruplar & $\bar{X}$ & SD & $F$ & $p^{*}$ \\
\hline \multirow{2}{*}{ Okul İçi Faktörler } & Alt & 3.52 & 0.69 & \multirow{2}{*}{149.78} & .000 \\
& Üst & 4.65 & 0.26 & & \\
\hline \multirow{2}{*}{ Okul Dış1 Faktörler } & Alt & 2.17 & 0.53 & \multirow{2}{*}{146.34} & .000 \\
& Üst & 3.52 & 0.71 & & .000 \\
\hline Mesleki Gelişim ve & Alt & 2.96 & 0.74 & \multirow{2}{*}{186.89} & \\
\hline \multirow{2}{*}{ Fayginlık } & Üst & 4.45 & 0.48 & & .000 \\
& Alt & 2.88 & 0.70 & \multirow{2}{*}{177.02} & \\
\hline
\end{tabular}

$p<.01$. 
Tablo 4'te görüleceği gibi alt faktörler için yapılan ANOVA testleri de anlamlı sonuç vermekte alt ve üst gruplar arası farklılaşmanın anlamlı olduğunu ortaya koymaktadır. Sonuçlar ölçeğin ayırt edicilik gücünün yüksek olduğunu göstermektedir.

\section{Puanlama}

Öğretmen Mesleki Motivasyonu Ölçeği dört faktör altında 5'li Likert tipinde 25 maddeden oluşmaktadır. Ölçekte ters puanlanması gereken madde bulunmamaktadır. 1, 2, 3, 4, 15 ve 16. maddeler fiziki imkânlar alt boyutunu, 5, 6, 7, 8, 9, 10, 11, 12, 13 ve 14. maddeler okul içi faktörler alt boyutunu, 17, 18, 19, 20 ve 21. maddeler okul dışı faktörler ve 22, 23, 24 ve 25. maddeler mesleki gelişim ve saygınlık alt boyutunu oluşturmaktadır. Alt faktörlere ilişkin puanlar, bu faktör altındaki maddelerin toplamı ile bulunabilir. Ölçek puanı ise alt faktör puanlarının toplamı ile elde edilir. Ölçekten alınacak toplam puan 25 ile 125 arasında değişmektedir. Mevcut çalışmada elde edilen puanlar hem çevrim içi uygulama için hem de kâğıt kalem uygulaması için ise 25 ile 125 arasında değişkenlik göstermiştir.

\section{Tartışma ve Sonuç}

$\mathrm{Bu}$ çalışmada, öğretmenlerin motivasyon düzeylerini mesleki faktörler bağlamında değerlendirmeye yardımcı olacak geçerli ve güvenilir bir ölçme aracı geliştirmek amaçlanmıştır. Öğretmen ve yöneticilerle yapılan görüşmeler ve ilgili alanyazın doğrultusunda, öğretmen motivasyonunu etkileyen unsurlar maddeleştirilerek ölçme aracının ilk formu elde edilmiştir. Ölçme aracının geçerlik ve güvenirlik analizleri için üç farklı çalışma grubundan veri toplanmıştır. Çevrimiçi ve kâğıt-kalem yoluyla toplanan veriler üzerinde ayrı ayrı gerçekleştirilen geçerlik ve güvenirlik analizleri, “Öğretmen Mesleki Motivasyonu Ölçeği”nin, okullarda öğretmen motivasyonunu değerlendirmek üzere araştırmacı ve uygulamacılar tarafından kullanılabilecek, kültürel, toplumsal ve kurumsal bağlama duyarlı, ayırt ediciliği güçlü, geçerli ve güvenilir bir ölçme aracı olduğuna dair güçlü kanıtlar sunmaktadır. Ölçeğin iç güvenirliğinin de yüksek olduğu ve alt boyutlarının birbirinden farklı özellikleri bir bütünlük içinde değerlendirdiği görülmektedir.

Ölçme aracı ile ilgili yapısal analizler, öğretmen motivasyonunun; okul içi faktörler, okul dışı faktörler, fiziki imkânlar ve mesleki gelişim ve saygınlık olmak üzere dört alt boyutta değerlendirilebileceğini ortaya koymuştur. Okul içi faktörler alt boyutu öğretmenlerin okul içinde öğrenci, meslektaş ve yöneticileri ile kurmuş oldukları mesleki ve kişisel iletişim, öğrenci başarısı vb. unsurlar ile ilgilidir. Okul dışı faktörler alt boyutu; eğitim programı, ders kitapları, iş yükü, ücret gibi daha çok merkezi politikalarla ilgili 
unsurlardan oluşmaktadır. Mesleki gelişim ve saygınlık alt boyutu, öğretmenlerin meslek sevgisi, mesleğin saygınlığı ve gelişime açıklığı gibi unsurlardan kaynaklanan motivasyon düzeylerini değerlendirmektedir. Ölçme aracının son alt boyutu fiziki imkânlar ise okula sağlanan sosyal destek ve fiziki ortamın niteliği ve araç gereç ve eğitim teknolojilerine ulaşılabilirlik ile ilgili maddelerden oluşmaktadır.

Alanyazındaki öğretmen motivasyonu ile ilgili çalışmalarda (Akdemir ve Arslan, 2013; Claeys, 2011; Kauffman, Y1lmaz-Soylu ve Duke, 2011; Öztürk ve Uzunkol, 2013; Visser-Wijnveen, Stes ve Petegem, 2012) içsel ve dişsal motivasyon faktörlerinin birbirine yakın kavramsal bağlamlarda ele alındığı görülmektedir. Akdemir ve Arslan (2013) tarafından yapılan çalışma, öğretmen motivasyonunu; iletişim, mesleki gelişim, kurum ve beklentiler alt boyutlarında değerlendirmektedir. Öztürk ve Uzunkol (2013) tarafindan yapılan çalışmada ise öğretmen motivasyonu; "mesleğe yönelik olumlu tutum ve mesleki başarı", "takdir edilme ve mesleki mutluluk", "meslekten kaçınma” ve "mesleği özümseme” olmak üzere dört alt boyutta ele alınmaktadır. Söz konusu araştırmalardan farklı olarak bu çalışmada, sosyoekonomik faktörler ve eğitim politikalarının öğretmenler üzerindeki etkileri de değerlendirme kapsamına alınmıştır. Öğretmen motivasyonunun; FATİH Projesi, 12 yıllık zorunlu eğitim sistemi, müfredat çalışmaları gibi ulusal eğitim politikalarından olumlu ya da olumsuz yönde etkilendiğini ortaya koyan bazı nitel araştırma bulguları (Ada, Akan, Ayık, Yıldırım ve Yalçın, 2013; Börü, 2018; Ertürk ve Aydın, 2017; Karabağ-Köse ve diğerleri, 2018), çalışmanın bu alandaki katkısını daha önemli hale getirmektedir. Bunun dışında alanyazında yer alan öğretmen motivasyonu ile ilgili bazı ölçek çalışmalarının (Bektaş, 2010; Ceviz, 2018; Polat, 2010) veli, öğrenci, okul, eğitim politikaları ve diğer eğitim süreçleri ile ilgili bazı bağlamları kapsamına almadığı görülmektedir. Alanyazında yer alan ölçek çalışmaları metodolojik açıdan değerlendirildiğinde, pek çok çalışmada ölçme araçlarının yapısal özelliklerinin ve güvenirlik düzeylerinin güçlü analizlerle test edilmediği, bazı çalışmalarda ise elde edilen kavramsal modellerin uyumunun DFA ile değerlendirilmediği görülmektedir (Akdemir ve Arslan, 2013; Bektaş, 2010; Polat, 2010). Dolayısıyla bu çalışma kapsamında geliştirilen ölçeğin araştırmacı ve uygulamacılar için kullanışlı, kültürel bağlama duyarlı, geçerli ve güvenilir bir araç olarak alanyazında bir boşluğu dolduracağı çıkarımı yapılabilir. Çevrimiçi ve kağıt-kalem uygulamalarının her ikisinde de geçerli ve güvenilir sonuçlar elde edilmesi, ölçeğin her iki yöntemle veri toplamak için kullanılabileceğini göstermektedir. 
E, Karabağ Köse, E, Karataş, M, Küçükçene ve A, Taş / Pamukkale Üniversitesi Eğitim Fakültesi Dergisi, 51, 479-498, 2021493

Araştırma genel olarak öğretmenlik mesleğine özgü motivasyon faktörlerini kapsamakla birlikte, çalışma gruplarının ilk ve orta dereceli okullar ile genel liselerde çalışan öğretmenlerden oluşması araştırmanın temel sınırlılığını oluşturmaktadır. Ölçme aracının okul öncesi öğretmenleri ve farklı alanlarda (mesleki eğitim, yetişkin eğitimi, özel eğitim, üstün yetenekliler vb.) çalışan öğretmenler gibi farklı çalışma koşullarına sahip öğretmen gruplarında ortaya koyacağı yapısal farklılıkları değerlendirmek üzere yeni araştırmalar yürütülebilir. Ölçme aracının eğitim araştırmalarında öğretmenlerin mesleğe yönelik motivasyon düzeylerini değerlendirmek üzere araştırmacılar tarafından kullanılması önerilmektedir. Ayrıca eğitim yöneticileri için de mesleğe yönelik öğretmen motivasyonunu değerlendirmeye yönelik geçerli ve güvenilir bir araçtır. 


\section{Kaynakça}

Ada, Ş., Akan, D., Ayık, A., Yıldırım, İ. ve Yalçın, S. (2013). Öğretmenlerin motivasyon etkenleri. Atatürk Üniversitesi Sosyal Bilimler Enstitüsü Dergisi, 17(3), 151-166.

Akdemir E. ve Arslan A. (2013). Development of motivation scale for teacher. Procedian Social and Behavioral Sciences, 106, 860-864.

Akman, Y. (2018). Investigating the relationship between organizational justice, work motivation and teacher performance. Çukurova Üniversitesi Ĕ̈itim Fakültesi Dergisi, 47(1), 164-187. doi: 10.14812/cuefd.371642

Aksel, N. ve Elma, C. (2018). Ortaokul müdürlerinin dönüşümcü liderlik davranışları ile öğretmenlerin motivasyonu arasındaki ilişki. Abant İzzet Baysal Üniversitesi Ĕ̆itim Fakültesi Dergisi, 18(3), 1252-1268.

Ballester-Arnal, R., Castro-Calvo, J., Gil-Julia, B., Giménez-García, C., \& Gil-Llario, M. D. (2019). A validation study of the Spanish version of the Hypersexual Behavior Inventory (HBI): Paper-and-pencil versus online administration. Journal of Sex \& Marital Therapy, 45(4), 283-302.

Bektaş, A. (2010). Illköğretim okulu yöneticilerinin sosyal iletişim becerileri ile sınıf ögretmenlerinin motivasyonu arasındaki ilişki. Yayımlanmamış Yüksek Lisans Tezi, Gazi Üniversitesi, Ankara.

Börü, N. (2018). The factors affecting teacher-motivation. International Journal of Instruction, 11(4), 761-776. doi: 10.12973/iji.2018.11448a

Can, S. (2015). Investigation of the motivation level of teachers working at state schools in relation to some variables. International Journal of Progressive Education, 11(3), 153-161.

Carson, R. L., \& Chase, M. A. (2009). An examination of physical education teacher motivation from a self-determination theoretical framework. Physical Education and Sport Pedagogy, 14(4), 335-353, doi: 10.1080/17408980802301866

Ceviz, H. (2018). Toplumdaki öğretmenlik meslĕgine ilişkin algl ile öğretmenin mesleki motivasyonu arasındaki ilişki. Yayınlanmamış Yüksek Lisans Tezi, Düzce Üniversitesi, Düzce. 
E, Karabağ Köse, E, Karataş, M, Küçükçene ve A, Taş / Pamukkale Üniversitesi Eğitim Fakültesi Dergisi, 51, 479-498, 2021495

Choi, S. (2014). A measure of English teacher motivation: Scale development and preliminary validation. Advanced Science and Technology Letters, 59, 85-88 doi: 10.14257/astl.2014.59.19

Claeys, L. (2011). Teacher motivation to teach and to remain teaching culturally and linguistically diverse students. Unpublished doctoral dissertation University of Texas, San Antonio.

Cole, D. A. (1987). Utility of confirmatory factor analysis in test validation research. Journal of Consulting and Clinical Psychology, 55(4), 1019-1031.

Çivilidağ, A. ve Şekercioğlu, G. (2017). Çok boyutlu iş motivasyonu ölçeğinin Türk kültürüne uyarlanması. Mediterranean Journal of Humanities, 7(1), 143-156. doi: 10.13114/MJH.2017.326

Davis, J., \& Wilson, S. M. (2000). Principals' efforts to empower teachers: Effects on teacher motivation and job satisfaction and stress. The Clearing House, 73(6), 349353. doi: 10.1080/00098650009599442.

De Jesus, S. N., \& Lens, W. (2005). An integrated model for the study of teacher motivation. Applied Psychology: An International Review, 54(1), 119-134. doi: 10.1111/j.1464- 0597.2005.00199.x

Deci, E. L., \& Ryan, R. M. (1985). Intrinsic motivation and self-determination in human behavior. New York: Plenum.

Demir, H. ve Okan, T. (2009). Motivasyon üzerinde ulusal kültür etkisi. Gazi Üniversitesi İktisadi ve İdari Bilimler Fakültesi Dergisi, 11(1), 121-142.

Determann, D., Lambooij, M. S., Steyerberg, E. W., De Bekker-Grob, E. W., \& De Wit, G. A. (2017). Impact of survey administration mode on the results of a health-related discrete choice experiment: Online and paper comparison. Value in Health, 20(7), 953-960.

Doğan, S. ve Koçak, O. (2014). Okul yöneticilerinin sosyal iletişim becerileri ile öğretmenlerin motivasyon düzeyleri arasındaki ilişki. Kuram ve Uygulamada Eğitim Yönetimi Dergisi, 20(2), 191-216.

Dündar, S., Özutku, H. ve Taşpınar, F. (2007). İçsel ve dışsal motivasyon araçlarının işgörenlerin motivasyonları üzerindeki etkisi: Ampirik bir inceleme. Ticaret ve Turizm Eğitim Fakültesi Dergisi, 2, 107-108. 
496 E, Karabağ Köse, E, Karataş, M, Küçükçene ve A, Taş / Pamukkale Üniversitesi Eğitim Fakültesi Dergisi, 51, 479-498, 2021

Emirbey, A. R. (2017). Okul yöneticilerinin etik liderlik davranışları ile öğretmen motivasyonu arasındaki ilişki. Yayınlanmamış Yüksek Lisans Tezi, Uşak Üniversitesi, Uşak.

Eren, E. (2004). Örgütsel davranışve yönetim psikolojisi. İstanbul: Beta Yayıncılık.

Ergeneli, A. ve Eryiğit, M. (2001). Öğretim elemanlarının iş tatmini: Ankara'da devlet ve özel üniversite karşılaştırması. Hacettepe Üniversitesi Íktisadi ve İdari Bilimler Fakültesi Dergisi, 19(2), 159-178.

Ertürk, R. ve Aydın B. (2017). Öğretmenlerin iş motivasyonunu artıran ve olumsuz etkileyen durumların incelenmesi. The Journal of Academic Social Science, 5(58), $582-603$.

Fernet, C., Senécal, C., Guay, F., Marsh, H., \& Dowson, M. (2008). The work tasks motivation scale for teachers (WTMST). Journal of Career Assessment, 16(2), 256279. doi: $10.1177 / 1069072707305764$

Gefen, D., Straub, D. W., \& Boudreau, M. (2000). Structural equation modeling and regression: Guidelines for research practice. Communications of the Association for Information Systems, 4(7), 1-78.

Güçlü, N., Recepoğlu, E. ve Kılınç, A. Ç. (2014). İlköğretim okullarının örgütsel sağlığı ile öğretmenlerin iş motivasyonları arasındaki ilişki. Hacettepe Üniversitesi Ĕ̆gitim Fakültesi Dergisi, 29(1), 140-156.

Han, J., \& Yin, H. (2016). Teacher motivation: Definition, research development and implications for teachers. Cogent Education, 3(1), 1217819, 1-18.

Hofstede, G. (2001). Culture's consequences: Comparing values, behaviors, institutions, and organizations across nations. Thousand Oaks, CA: Sage.

Karabağ-Köse, E., Taş, A., Küçükçene, M. ve Karataş, E. (2018). Öğretmen motivasyonunu etkileyen faktörlere ilişkin yönetici ve öğretmen görüşleri üzerine karş1laştırmalı bir inceleme. MAKU Eğitim Fakültesi Dergisi, 48, 255-277. doi: $10.21764 /$ maeuefd.424729

Kauffman, D. F., Yılmaz-Soylu, M. ve Duke, B. (2011). Öğretme motivasyonu ölçeğinin geçerlik çalışması. Hacettepe Üniversitesi Ĕ̈itim Fakültesi Dergisi, 40, 279-290.

Koçel, T. (2005). İşletme yöneticiliği. İstanbul: Arıkan Yayınevi. 
Kurt, T. (2005). Herzberg in çift faktörlü güdüleme kuramının öğretmenlerin motivasyonu açısından çözümlenmesi. Gazi Üniversitesi Gazi Eğitim Fakültesi Dergisi, 25(1), 285-299.

Küçüközkan, Y. (2016). Liderlik ve motivasyon teorileri: Kuramsal bir çerçeve. Uluslararası Akademik Yönetim Bilimleri Dergisi, 1(2), 86-115.

Lind, T. C. (2017). Relationships among principal leadership behaviors, teachers' motivation, and teacher job satisfaction. Unpublished doctoral dissertation, Northern University of Illinois.

Mahaney, C. R., \& Lederer, A. L. (2006). The effect of intrinsic and extrinsic rewards for developers on information systems project success. Project Management Journal, $37(4), 42-54$.

McDonald, R. P., \& Ho, R. H. (2002). Principles and practice in reporting structural equation analyses. Psychological Methods, 7(1), 64-82.

Ng, C. F., \& Ng, P. K. (2015). The motivation of English language teachers in a language centre. International Journal of Languages, Literature and Linguistics, 1(2), 87-92.

Nie, Y., Chua, B. L., Yeung, A. S., Ryan, R. M., \& Chan, W. Y. (2014). The importance of autonomy support and the mediating role of work motivation for well-being: Testing self-determination theory in a Chinese work organisation. International Journal of Psychology, 50(4), 245-255. doi: 10.1002/ijop.12110

Oksay, A. (2005), Çalışanlarda iş tatmini: Să̆llk sektörü üzerine bir araştırma. Yayınlanmamış Yüksek Lisans Tezi, Süleyman Demirel Üniversitesi, Isparta.

Öztürk, E. ve Uzunkol, E. (2013). İlkokul öğretmeni motivasyon ölçeğinin psikometrik özellikleri. Eğitimde Kuram ve Uygulama, 9(4), 421-435.

Pinder, C. C. (2014). Work motivation in organizational behavior. New York: Psychology Press.

Polat, S. (2010). Okul öncesi yöneticilerinin kullandıkları yönetsel güç kaynaklarına ilişkin ögretmen alglları ile öğretmen motivasyonu arasındaki ilişki. Yayınlanmamış Yüksek Lisans Tezi, Yeditepe Üniversitesi, İstanbul.

Roth, G., Assor, A., Kanat-Maymon, Y., \& Kaplan, H. (2007). Autonomous motivation for teaching: How self-determined teaching may lead to self-determined learning. 
Journal of Educational Psychology, 99(4), 761-774. doi: 10.1037/00220663.99.4.761

Ryan, R. M., \& Deci, E. L. (2000). Intrinsic and extrinsic motivations: Classic definitions and new directions. Contemporary Educational Psychology, 25(1), 54-67, doi: 10.1006/ceps.1999.1020.

Ryan, R. M., \& Deci, E. L. (2011). A self-determination theory perspective on social, institutional, cultural, and economic supports for autonomy and their importance for well-being. In C. V., R. R., \& S. K. (Eds.) Human Autonomy in Cross-cultural Context (s. 45-64). Dordrecht: Springer.

Sieberer-Nagler, K. (2016). Effective classroom-management \& positive teaching. English Language Teaching, 9(1), 163-172.

Stirling, D. (2014). Motivation in education. Learning Development Institute.

Tabachnick, B. G., \& Fidell, L. S. (2013). Using multivariate statistics. Upper Saddle River, NJ: Pearson Publication, Inc.

Thoonen, E. E. J., Sleegers, P. J. C., Oort, F. J., Peetsma, T. T. D., \& Geijsel, F. P. (2011). How to improve teaching practices: The role of teacher motivation, organizational factors, and leadership practices. Educational Administration Quarterly, 47(3), 496536. doi: 10.1177/0013161X11400185

Tinsley, H. E., \& Tinsley, D. J. (1987). Uses of factor analysis in counseling psychology research. Journal of Counseling Psychology, 34(4), 414-424.

Viseu, J., De Jesus, S. N., Rus, C., \& Canavarro, J. M. (2016). Teacher motivation, work satisfaction, and positive psychological capital: a literature review, Electronic Journal of Research in Educational Psychology, 14(2), 439-461.

Visser-Wijnveen, G. J., Stes, A. S., \& Petegem, P. V. (2012). Development and validation of a questionnaire measuring teachers' motivations for teaching in higher education. Higher Education, 64(3), 421-436. doi: 10.1007/s10734-011-9502-3

Yılmaz, F. (2009). Ĕgitim örgütlerinde örgüt kültürünün öğretmenlerin iş motivasyonu üzerindeki etkisi. Yayınlanmamış Yüksek Lisans Tezi, Selçuk Üniversitesi, Konya. 
Aşağıda verilen motivasyon unsurlarının çalışma isteğinizi etkileme durumunu

1 - Çok olumsuz etkiler 5 - Çok olumlu etkiler olacak şekilde derecelendiriniz.

\begin{tabular}{cc}
\hline Çok & Çok \\
Olumsuz & Olumlu
\end{tabular}

\begin{tabular}{|c|c|c|c|c|c|}
\hline 1. Okulumuzdaki fiziki ortamın niteliği & 1 & 2 & 3 & 4 & 5 \\
\hline 2. Okulumuzda yeni teknolojilerin kullanılabilirliği & 1 & 2 & 3 & 4 & 5 \\
\hline 3. Okulumuzda ihtiyaç duyulan araç gerecin sağlanabilirliği & 1 & 2 & 3 & 4 & 5 \\
\hline 4. Okulumuzdaki sosyal-sportif faaliyet sayısı & 1 & 2 & 3 & 4 & 5 \\
\hline 5. Okulumuzdaki ortamın samimiyeti & 1 & 2 & 3 & 4 & 5 \\
\hline 6. Okulumuzda insana verilen değer & 1 & 2 & 3 & 4 & 5 \\
\hline 7. Okulumuzda yapılan çalışmaların takdir edilme düzeyi & 1 & 2 & 3 & 4 & 5 \\
\hline 8. Okulumuzdaki öğrencilerin başarı durumları & 1 & 2 & 3 & 4 & 5 \\
\hline 9. Çalışmalarımın öğrenciler üzerindeki etkileri & 1 & 2 & 3 & 4 & 5 \\
\hline 10. Okulumuzdaki mesleki işbirliği ve dayanışma düzeyi & 1 & 2 & 3 & 4 & 5 \\
\hline $\begin{array}{l}\text { 11. Okulumuzda öğretmenlerin okul ile ilgili konularda karara } \\
\text { katılım durumu }\end{array}$ & 1 & 2 & 3 & 4 & 5 \\
\hline 12. Okulumuzda adaletin işleyişi & 1 & 2 & 3 & 4 & 5 \\
\hline 13. Okul yöneticilerimizin davranışları & 1 & 2 & 3 & 4 & 5 \\
\hline 14. Ders saati, nöbet vb. taleplerimin dikkate alınma durumu & 1 & 2 & 3 & 4 & 5 \\
\hline 15. Velilerin okula destek sağlama durumu & 1 & 2 & 3 & 4 & 5 \\
\hline 16. Okulumuzun bulunduğu sosyoekonomik çevre & 1 & 2 & 3 & 4 & 5 \\
\hline 17. Eğitim politika ve uygulamalarındaki değişimler & 1 & 2 & 3 & 4 & 5 \\
\hline 18. Bakanlıkça hazırlanan eğitim programları & 1 & 2 & 3 & 4 & 5 \\
\hline 19. Bakanlıkça hazırlanan ders kitapları & 1 & 2 & 3 & 4 & 5 \\
\hline 20. Mesleğin iş yükü & 1 & 2 & 3 & 4 & 5 \\
\hline 21. Aldığım ücret düzeyi & 1 & 2 & 3 & 4 & 5 \\
\hline 22. Mesleğin saygınlı̆̆ & 1 & 2 & 3 & 4 & 5 \\
\hline 23. Mesleğime olan sevgim & 1 & 2 & 3 & 4 & 5 \\
\hline 24. Mesleğimin kişisel ve mesleki gelişim imkânları & 1 & 2 & 3 & 4 & 5 \\
\hline $\begin{array}{l}\text { 25. Alanımla ilgili yayınlara erişim imkânları (makale, dergi, } \\
\text { kitap vb.) }\end{array}$ & 1 & 2 & 3 & 4 & 5 \\
\hline
\end{tabular}

* Ölçek atıf yapılarak akademik çalışmalarda kullanılabilir. Ölçek maddelerinin alt boyutlara göre dağılımları Puanlama bölümünde verilmiştir. 